\title{
Ethical evaluation of Labour Union strikes in Nigeria and the religious value of the dignity of labour
}

\author{
Olusegun Peter Oke Ph.D \\ Department of Religious Studies, \\ University of Ibadan, Ibadan, Nigeria \\ E-mail: okeolusegun25@gmail.com
}

$\&$

\author{
Elizabeth Okoh John \\ Department of Religious and Cultural Studies \\ University of Calabar, Nigeria \\ Doi: https://doi.org/10.46222/pharosjot.10245
}

\begin{abstract}
Agitations by labour unions in the country have become a recurring decimal and this has led to a series of arrests and death of members in the course of fighting for their legitimate rights of improved welfare packages. In this incessant face- off between government and labour unions in the country, many scholars have written voicing the opinions. While some blamed successive government on their insensitivity to the plight of Nigerian workers, others condemned the actions of workers as falling below expectation as many are inefficient and incompetent. But, an area where attention has not been focused on, has to do with the value of dignity of labour among the Nigerian workforce. It is therefore pertinent to take a critical look at the religious value of the dignity of labour vis - a - vis the attitudes of those in the corridors of power and the plight of workers who are the fulcrum on which the economy upon which any nation stands. It is in light of this that this paper will examine among other things, strike actions in Nigeria, and the meaning of 'dignity of labour' from a religious perspective. Lastly, a clarion call will be made on stakeholders in labour matters on the need to address the lingering gridlock between government and labour unions in the country in order for the efforts of the present administration at revamping the economy not to be a mere waste of time
\end{abstract}

Keywords: Ethics, evaluation, strike, dignity of labour, socio-economics.

\section{Introduction}

It is a known fact that the strength and success of any nation depend to a large extent on the quality, effectiveness, commitment and efficiency of its workforce and leaders (Okoye \& Ezeigbo, 2013; Nicolaides \& Duho, 2019). But, in a country where workers groan under very bad and severe economic hardships such as delayed/ non-payment of salaries, pensioners dying while on queue to get their pension, insecurity, incessant 'epileptic' power supply, fuel scarcity leading to loss of quality hours and bringing untold hardship on the workers and the masses who have already been impoverished by the lack of electricity supply and the near collapse of the energy sector (socialistnigeria.org.), things are indeed bleak. There is no doubt that the economy of such a nation will experience a developmental 'kwashiorkor'. The change agenda mantra's effort will be a futile one if the workforce in the country are not happy because of non-payment of their salary for months. 
Despite this, government agencies are increasing prices of social services like electricity and spiraling food prices. (venturesafrica.com)

\section{Striking in Nigeria}

Before we go on to our discussion, it is very important for us in this work to examine the etymology of striking in Nigeria in order to have a better understanding of its genesis and its connection with religious value of dignity of labour. A strike has been defined variously by scholars from different fields of human endeavours. One definition sees a strike as a situation where workers refuse to work as a protest or labour revolt, and they may walk away from their duty post. It is also defined as a process by which organizations organized are stopping the work of employees because of some disagreement in wages and salaries (http//search definition of strike.com). Strike action has become a phenomenon in Nigeria because the labour leaders and the workforce at large, believe that the only language those in authority understand is a strike (Aremu, 2015). Agitations and counter agitations by workers is not peculiar to Nigeria alone as other nations in the world have their own share of strike action. In Nigeria for instance, strikes have a great impact on every sector of our national life (articlesng.com).

The impact of a strike action is mammoth and this accounts for why the country has remained underdeveloped since independence. Striking imposes a serious 'bite' on the economy, education, health and social life etc. (articlesng.com). The first general strike in Nigeria was the Railway workers strike of 1945 (http//.comsearch. Nigeria railway workers strike of 1945). Before that, there were pockets of strikes such as the Aba women riot of 1929 (www.pulse.ng.news.local), the Railway workers strike of 1939 (http//.www.railway workers of 1939), the Nigerian Union of Railway men strike of 1941 (https//www.vanguardng.com,2012), the U.A.C employees in 1947, Coal Miners' strike of 1949 (Ro.uow.edu/cgi/viewcontentcgi) the Mercantile workers' strike 1951 (https//www. google.com.mercantile -strike-of 1951), the Airways Workers Union strike of 1959 (https//www. google.com.airway -strike-of 1959). All these severe strikes took place before independence.

\section{Types of Strike}

For the purpose of emphasis, there are various types of strike embarked upon by workers to press home their demand for improved conditions of service. Few of them are discussed seriantim.

Emergency strike: This type of strike is a serious and dangerous one. It is usually carried out in events and situation which need urgent attention.

Jurisdictional strike: The expectation that the organization must make a legal decision about something and the refusal to make it, or if the decision is not favourable to the union, it will cause strike.

Go- Slow: This is a type of strike where workers do their work more slowly than usual. They do this on many occasions to call the attention of the management or government to address certain issues. If the management refuses to listen to the union, they embark on strike.

Boycott: This is a situation where workers refuse to take part in something. For example, when lecturers refuse to teach.

Sympathy: This is a type of strike where a union embarks on strike to show sympathy in support of another union who has embarked on strike.

Wildcat: Sudden and an unauthorized stoppage of work. This type of strike is not approved by union leaders (https// simple.wikipedia.org./wiki/). 


\section{Causes of strike actions in Nigeria}

A strike does not just occur. It occurs for various reasons. It can be for improved welfare services for union members, payment of salaries and wages or in solidarity for other or sister union(s) (http://dailypost.ng, 2017). A Strike becomes inevitable because of the insincerity and the noncompliance of government and management to agreementS jointly reached by the two parties (http://www.pmnewsng.com). One of the major causes of strike in Nigeria is the unfair treatment of workers. Government agencies on many occasions fail to fulfill promises made to their workforce (https://files.eric.ed.gov/fulltext/EJ1082726.pdf). Many are working under a de-humanized conditions. Workers complain of the refusal of government agencies to promote members who are due for such, pensioners not given their entitlements. Victimization of workers is also another cause of strike (https://nigeriacommunicationsweek.com.ng/nigcomsat-workers-threaten-to-shut-down).This is very common in private organizations, where workers are victimized unduly. Some who sustain various degrees of injury are abandoned; many union leaders are victimized for their just agitation. Nonobservation of the provision of collective bargaining is one other causes of agitations by union members(www.nigerianlawguru.com/.../labour\%20law/collective\%20bargaining,\%20.).

Both government and private organizations' failure to implement suitable conditions of work as contained in their letters of appointment has given rise to incessant agitations by union leaders in the country. They give excuses for their non-implementation of the agreement (https://www.dailytrust.com.ng/news/education/towards...strikes.../195650.html).

\section{Effects of strike action}

To say that strike actions have seriously affected the nation is to say the least. In fact, there is no sector that has not felt the impact of strike and agitations by labour unions in Nigeria. For instance, the effects of strike action and industrial disharmony that result when workers and employers are unable to come to a level of compromise have negative and unpalatable effect on the economy (Effect of strike action on development. https://www.ajol.info/index.php/ijah/article/download/107554/97407). Such negative effects have both macro and micro implications on the economy of the nation. Considering the effect from the macro level, workers lose their pay and this affects the workers market purchasing power and they then have an inability to pay their children school fees and attend to other domestic responsibilities. From the micro angle, employers whose workers are on strike lose the union services and as a result of this, their capacity for production will be badly affected which will invariably have an adverse effect on returns and profit margin. At the long-run, the society largely bears the brunt. This is apposite to the saying among the Yoruba that "Tí erin méji bá jà, koríko ilè ni yóo jìyà rẹ̀. When two elephants fight, it is the grass that suffers.

Another area where the gridlock has really affected is the education sector. Over the years, students in the country's citadel of learning have really suffered from the incessant strike actions embarked upon by the Academic Staff Union of Universities (ASUU) in Nigeria and the Non-Academic Staff of the Universities (NASU). (https://omojuwa.com/.../asuu-strike-causes-and-implication-of-educationworkers-strike). This is because, at every industrial crisis, students are always at the receiving end (https://www.grossarchive.com/). They are forced to go home and they study to pass and not for knowledge acquisition and this has affected the academic performance of students in higher institution of learning making our certificates and degrees unacceptable in many schools abroad (thenationonlineng.net/fed-govt-accuses-lecturers-bad-faith-asuu-begins-strike). Strike action has brought down the standard of education in the country to the extent that many of our graduates are said to be unemployable by companies (https://www.vanguardngr.com > News). This is the reason why most employers of labour in Nigeria now insist on second-class upper division and above from 
their applicants. In some cases, higher institutions lose a whole academic year as a result of the unresolved industrial crisis.

The health sector is not left out in the web of incessant strikes by health workers. Strike actions by those in the health sector have affected healthcare delivery in Nigeria and this has really slowed down and irredeemably destroyed Nigeria's public healthcare system. Due to the incessant strike actions by those in the health sector, many who have the money have resorted to travelling abroad for medical attention while those who could not afford such medical attention overseas have resigned to their fate. Many have also lost their lives. What this means is that patients are getting used to seeking their healthcare outside the public sector and many that can afford to do so, go to the private hospitals (https://www.ncbi.nlm.nih.gov/pmc/articles/PMC4962455/).

\section{What is dignity of labour?}

In a simple language, dignity of labour means that all occupations, whether involving intellectual or physical labour deserve equal respect and dignity (https://www.thenigerianvoice.com/news/144351/1/dignity-of-labour.html). No job should be considered superior or inferior to another. Every job that is done dutifully with honesty and sincerity deserves appreciation. Intellectual and manual work are two types of labour (https://www.thebalance.com > Investing > US Economy > Supply). But, whatever it is, it has its dignity. The people that work with their hands are as important and useful as those using their intellectual skills. The wealth of any nation is created by the work of labour (https://www.adamsmith. org/thewealth-of-nations). If man ceases to work, humanity will be in trouble. Therefore, work is a positive human act. When one looks at the country, one will sees a variety of work (Utomi, 2004). Some are employed in government establishments, the civil service or public corporation; others are selfemployed and there are others who are unemployed. Wherever one works, the principle of dignity of labour "laborare dignitatem" implies that whatever one does that feeds and enables him to be clothed should be respected and not degraded (https://www. the balance.com > ... > Human Resources > Workplace Communication) or treated with contempt (Grint.1991). In fact, one should not see such as an opportunity to embezzle money meant for the good of the people as we see in the country today, where those appointed or elected into positions of authority have abused the office through series of unbridled impunity all over and indulge in corrupt practices (Nicolaides \& Duho, 2019; www.monitor.upeace.org/innerpg.cfm?id_article=938).

To respect a particular work, invariably implies that one should approach his or her work with all the sense of responsibility and diligence it deserves (https://www.thebalance.com > ... > Human Resources > Workplace Communication). But, the situation in Nigeria today has made it practically impossible as many go around with $A$ kii sisé oba làágùn (government work does not deserve any seriousness) syndrome which has over the years reduced the level of productivity and commitment and the resultant effect is the economic hardship being experienced. Most workers see government work as nobody's business. They get to work late; they are often not dedicated to duty, as some of them see bribery as a way of life as they engage in corruption and embezzlement of funds, since their take-home pay cannot take them home. In most cases, the bulk of the blame is on the government. This is because the job they (civil servants) do should offer them a reward (salary) that will enable them to live as human beings. But, unfortunately, where is the reward as many states are owing their workers up to six months wages (https://www.business.govt.nz/hiringand...employment/dismissal-or-termination). This is the main reason why the economy is 'comatose'. When workers are not paid, market women will suffer the consequences, artisans will also not to be left out in the unpalatable experience (www.academia.edu/.../EFFECT_OF_NONPAYMENT_OF_SALARIES_TO_CIVI). This is why it is difficult in this paper to limit the argument to the civil servants alone since any problem that affect the economy does not affect the civil servants 
only but invariably also affects other strata of the society. It is on this note that Pope Leo's encyclical wrote on the "Rerum Novarum" (Of New Things) where he submitted that "equity commands that public authority show concern for the workers so that from what they may receive will enable them to be housed, clothed and secured, to live their life without hardship"(www.cacatholic.org/teachings/catholic-social...encyclicals/rerum-novarum-new-things)

The situation is so appalling in Nigeria that a man with N18, 000.00 minimum wage as salary in any state of the country will find it extremely difficult to live a comfortable life. Such an individual will resort to cutting corners to make ends meet. This is the situation that Nigeria workers find themselves in. To him, commitment to work will not make any sense to him. Jobs that do not translate into improved living conditions will not inspire him or her to work hard. What we have is a dead as opposed to living wage. Dead wages make for pauperism (https://www.omicsonline.org/.../low-income-anddiminishing-productivity-in-nigerian). A secondary school teacher Mr. Nasiru Lukuman reportedly collapsed at Saint Luke Grammar School Molete while in the classroom on the $13^{\text {th }}$ of May, 2016. Another man, Mr. Emmanuel Olajide, the Vice Principal of the same Saint Luke Grammar School, Molete died due to his inability to buy needed medications. The wife to Mr. Nasiru Lukuman said the government has not paid her husbands salary for months and this has made living a comfortable life a mere mirage (saharareporters.com/.../unpaid-salaries-teacher-slumps-school-vice-principal-deadoyo). It is now a common practice for parents who have their wards in private schools to sign a Memorandum of Understanding (MoU) with school owners on how to pay school fees of their wards (punchng.com/many-parents-cant-pay-childrens-fees-abroad-now-come-us-babcock-vc). Another bitter truth is that $60 \%$ of workers don't go to work anymore. Others make shift arrangements among themselves (https://workology.com/time-off-request-exempt-non-exempt-employee) "Inú dídùn, ní í mórí íyá" Happiness brings about enthusiasm to work. Apart from those in oil companies, banks, international organizations and few corporations, there is scarcely any establishment privately or government owned that pays living wages. This is why the attitudes of civil servants to work are often viewed with understanding and leniency. Often, they do not approach their work with required seriousness.

\section{The origin of Workers Day celebration}

For the purpose of clarity, it is important to examine the genesis of workers day celebration and see if the day really deserves to be celebrated, particularly in Nigeria where hunger and poor living conditions have become common. This is why it is necessary to take a look at what led to the celebration. The celebration started in the late $19^{\text {th }}$ Century, when the working class was in constant struggle to gain the 8-hour work day. Before the struggle, working conditions were severe and it was common to work for 10-16 hours daily in unsafe conditions. Death and injury were commonplace at many workplaces. As early as 1860's, working people agitated to shorten the work day without cuts in pay, but, it was not successful until the late 1880's when organized labour was able to garner enough strength to declare the 8-hour work day. This proclamation was without the consent of employers, yet demanded by many of the working class. Thousands of men, women, children are dying needlessly every year in the workplaces with life expectancy as low as early twenties in some industries and with little hope, but high destitution (https://www.thoughtco.com > Humanities > History \& Culture > American History). At its national Convention in Chicago in 1884, the Federation of Organized Trades and Labour Union later called American Federation of Labour, proclaimed that eight hours shall constitute a legal day's labour from May 1, 1886. This marked the beginning of the celebration. 


\section{Religious Values of Dignity of Labour}

Before we go into our discussion on religious values as they relate to dignity of labour, it is important to consider what we mean by ethics vis-à-vis its relevance to the attitude of those at the corridors of power in Nigeria. By ethics, we mean moral rules or moral behaviours for deciding what is right and what is wrong and knowing how to act in a moral dilemma situation (Nicolaides \& Duho, 2019). Ethics then refers to a standard of behaviour expected of members of society. It is important to discuss this because society expects its members to behave in a certain way and not to behave otherwise. This is the concern of ethics. The importance of dignity of labour is exemplified in African Maxims, proverbs and various ways of greeting people at worksites. For instance in Tanzania, Julius Nyerere of Tanzania stated that among the Swahilli "Treat your guest as a guest for two days and the third day, give him a hoe". This underscores the typical moral obligation of traditional African society. Also, among the Ewe of Ghana, "Any person who goes to draw water does not drink mud". This implies that through labour, one gets what one wants and enjoys the fruit of his labour. But, a critical look at the situation in Nigeria today shows that those who labour do not get what they want as a result of corruption and embezzlement of public funds by some of those in government. The Yoruba people of South west are not left out in this as they also use folksongs that extol, and instill the spirit of dignity of labour into their children. A typical example is the song found at www.opinions.ng/read-ise-logunise- yoruba- poem-j-f-odunjo-english-translation:

Isẹ Àgbè nisé ilè wa

Eni kò sisé yó mà jalè

İwé kíkó lài ní okó àti àdá

Kò ípe o, kò Í pè o.

Another one says:

Isé loògùn isè

Múra sí sé rẹ òré mi

Isé la fí dẹni giga

Bí a kò bá rẹni fẹ̀hìn tì

bí òle làá rí

Bí a kò bá réni gbékèlé

A te ra mó śe eni

lyá rẹ lè lówó lówó

Kí bàbá lẹsin lékà

Tó bá gbójú lé wọn

O tẹ tán ni mo so fún o

Ohun tí a kò jìyà fún kò ń tójó

Ohun a bá fara sise fún ló ń pe lówó eni

Apá lará, igùipá ni ìyékan

Bi ayé bá ńfé o lónií

Bi o bá lówó lówọ́, a tún fẹ o ló la

Àbí kóo wà ní ipò àtàtà

Ayé á yé o si tèrín tẹrín

Jé kí o di eni tí ń rágó

Kóo ri bí wọn ti ń yínmú si o

lyà ń be fómo tí kò gbón,

Ekún ń be fómo tí ń sá kiri

Má f'òwúrò seré òré mi

Múra sísé ojọ ṇ lo
Our work in Nigeria is farming

Anybody who does not work will steal Formal education without a hoe Is incomplete.

Work is the antidote to poverty

Work hard and work smart, my friend

Hard work and smart work bring about

success

When there is no one to rely on

Its like we are lazy

When there is no one to trust

We focus more on our work

Your mother might be rich

Your father might have one thousand and one horses

If you rely on them

In truth, you might be on sinking ground

What we did not suffer for does not last

But what we labour to achieve last long

Families are like the arms, extended families are

like the elbow

If the world loves you today

If you are rich, they will still love you tomorrow

as well or you are in an esteem position

You will be loved with fake laughter

If you unfortunately lose your position or wealth

You will discover how people will be mocking you

There is suffering for the foolish child

and there is sorrow for a child without a future plan

Don't waste your formative years, my friend

Work hard and plan well for the future. 
The poem by J.F Odunjo above states clearly the importance of dignity of labour and that anybody who is lazy will eventually steal. This shows that there is dignity in honest and sincere job. Yoruba people also add that "Ibi isé eni latí mo ni ló le." That is, you know if somebody is lazy by the attitude he displays towards his work. The need to work hard is also emphasized in this wise saying among the Yoruba. "Ejé ká f'ọmọdé sisế, kí á má bà fi àgbà siseẹ.."Let us work when we are young in order not to suffer at old age.

\section{The Christian stance on the dignity of labour}

In Christianity, the virtue of dignity of labour is well entrenched in many biblical passages. For instance, in Genesis 3:19. God created the world for six days and rested on the seventh day. If man is then created in the image and in the likeness of God, he needs to work hard. This is also made explicitly in Psalm 90:17 (www.crcbermuda.com/reference/ellen-white-books.../chap-10-the-dignityof-labour)." Man goes forth to work and to his labour until evening". Ecclesiastes 9:10 informs us that "Whatever your hand finds to do, do it with all your might, for in the grave, where you are going, there is neither working nor planning nor knowledge nor wisdom". Additionally, in Luke 10:7 we read: "Stay in that house, eating and drinking whatever they give you, for the worker deserves his wages. Do not move around from house to house". Galatians 6:2-5 urges us to carry each other's burdens, and in this way we fulfill the law of Christ. "If anyone thinks he is something when he is nothing, he deceives himself. Each one should test his own actions. Then he can take pride in himself, without comparing himself to somebody else, for each one should carry his own load". We are obliged to assist others to carry their burdens but without appropriating a person's responsibility to carry his or her own load.

The importance of work is also strongly emphasized in Proverbs 6:6-11."Go to the ant, thou sluggard; consider her way and be wise, which having no guide, overseer, or ruler provide her meat in the summer, and gathered her food in the harvest. How long will you sleep, o sluggard? When will you arise out of your sleep? Yet a little sleep, a little slumber, a little folding of the hands to sleep so shall your poverty come as one that travelled and your want as an armed man (https://www.biblegateway.com/passage/?search=Proverbs+6\%3A6-8\&version ).

From the Christian parlance, work is more than a way to make a living; it is a form of continuing participation in God's creation (https://www.cabrini.edu/about/departments/.../principles-of-catholicsocial-teaching). If the dignity of labour is to be protected, then the basic right of workers must be respected - right to productive work, to decent and fair wages, to the organization of and joining of unions, to private property and to economic initiatives (https://www.ethicaltrade.org/faq/isnt-it-jobgovernment-protect-worker). The ability to work is a gift of God's grace and we need to be enthusiastic about our work. God calls on us to do the work that is before us and this is a lifetime commitment and thus merits distinct honour, and must be rewarded.

Business is very dynamic and often severely challenged in diverse ways. The model workplace, has structures and relationships that work together around fundamental values and morals that transcend selfinterest and ethical behaviour. Core values stimulate ethical efforts as employees become encouraged to do the right thing at all times. It is often very difficult for employers and employees to know if what they decide is indeed the "right" thing. Holy scripture can assist as it throws some light on a particular situation and illuminates people. The Biblical moral law offers us ethical guidelines which are applicable to work and life situations. A biblical ethics of work which is presented is suggested as a yardstick for attitudinal change in employers and their employees. Such biblical ethics of work may well be of invaluable benefit to employers and employees irrespective of creed. (Nicolaides, 2020) 
In both the Old and the New Testament, work in the sense of profitable employment is seen as something that is self-evidently characteristic in human existence and given by God. The first

In Deuteronomy 15 we are informed that:

If there is among you anyone in need, a member of your community in any of your towns within the land that the Lord your God is giving you, do not be hard-hearted or tight-fisted toward your needy neighbor. You should rather open your hand, willingly lending enough to meet the need, whatever it may be (Deuteronomy 15:7-8).

The manner in which salaries are determined is indeed a spiritual issue and reflects on some core issues of moral theology, and not only from a Christian vantage point.

In Islamic milieu, the social status of a man is not determined by his vocation, but rather by his personal qualities as well as his actual (https://www.cabrini.edu/about/departments/.../principles-ofcatholic-social-teaching) contribution to the welfare of humanity. It is believed that a honest and efficient watch repairer is more honoured than a dishonest and inefficient President, Governor or public office holder. It is enshrined that man should enjoy the fruit of his labour in moderation and be grateful (Awoniyi, 2013). Making reference to the saying of Mohammed (S.A.W), "any Muslim who plants a plant or cultivate his plantation and a bird, or a human being or animal eats from it shall have a reward for charity. Definitely, misuse of labour and its attendant social virtues cut across the three major religions we practice in the country (Awoniyi, 2013).

\section{The Nigerian Situation}

In most states of the country, the relationship between government and the labour unions is characterized by controversy. Organized labour at one time or the other disagrees with those in power on a number of issues. What is different is the way a particular labour group or government has responded to issues of disagreement. Even in the developed countries of the world, the labour unions in as much as they are unrelenting and committed in contributing their own quota to national development, remain sensitive and uncompromising in matters pertaining to the welfare and good living condition of their members (http://ituc-africa.org/IMG/pdf). The Nigerian Labour Act is the consolidation of the laws relating to the labour code (cap 91 law of the federation of Nigeria, 1958) commenced on August 1, 1971. The aim among others is for the enhancement of dignity of labour with all its ramifications. By this, increase in productivity through the upliftment of workers will definitely increase the value for the society either implicitly or explicitly and this will bring good human relations at work and the quality of life of workers will improve. On the other hand, the society will be improved in general terms (https://mywage.org/nigeria/home/labour-law/trade-unions). The situation in Nigeria is embarrassing because, the effects of the dignity of labour are far below expectation. Every successive government in Nigeria always has a running battle with labour leaders as a result of their clamouring for improved working condition for their many members.

Nigerian workers are on a daily basis faced with poor conditions of service, outright frustrations at work, unstable security of job, sexual harassment, and vulnerability as they retire into poverty and lack. Many become pensioners dying while in a queue to get screened for their entitlements (https://leadership.ng/.../may-day-nigerian-workers-groan-under-economic-hardship). The above conditions have led most workers especially those working with government to engage in other private practices to subsidize their income since their wages are not sufficient for them to live a comfortable life. That is, their work (isế) is no longer medicine (oògùn) against poverty (isẹ́) as they wallow in 
abject poverty. Many of them ply the streets to beg for alms after retirement (https://gerialimi.blogspot.com.ng/2017/06/pensioners-take-to-begging-in-kwara.html).

What breeds under-development in Nigeria is the brazen corruption among politicians and political office holders and the bourgeois display of wealth illegally and immorally acquired with impunity. This is seen as part of the oppressive brutality and outrageous violence directed against the masses and all the people of Nigeria. The quickest way to be a millionaire overnight in Nigeria is to join a political party from where if you are lucky to be picked as a flag-bearer, and then after few months after, you will become a rich man or woman. Revelations have been made by The Chairman of the Presidential Advisory Committee against Corruption, Professor Itse Sagay (SAN) who said that N13Million allowance is being received by a senator as running costs, while Senator Shehu Sanni representing Kaduna Central at the Senate Chamber, also said each senator receives N700,000 monthly and 13.5Million as running costs (https://www.premiumtimesng.com/.../202692panamapapers-ex-nigerian-minister-bou). This is one reason why many politicians do everything possible to grab political power at all costs. What is really serious and painful is that corruption of all kinds has become an economic possibility, a chronically acute one, choking the breathing of our existence with all its adverse implications. What baffles one is how billions of Naira 'grows wings and flies into the thin air'.

The revelation in Panama papers where a whopping sum of $\$ 2.6$ million was reportedly traced to an ex-minister Rasheed Gbadamosi (Former Minister for Natural Planning) while serving as the Chairman of Petroleum Products Pricing Regulatory Agency (PPPRA) is a shame of unimaginable proportion in a country where every sector is sick and need urgent surgical operation to bring it back to life (https://www.premiumtimesng.com/.../202692-panamapapers-ex-nigerian-minister-bou.). This came from Mossack Foriseca of Panama law firm. Many other top politicians in the country are also indicted in the report. This is happening in a country where $80 \%$ percent of her citizens could not boast of three square meal in a day, where over 800,000 unemployed graduates applied for police job meant for 10,000 people, (https://www.tori.ng/news/.../8-things-you-need-to-know-as-police-fixesdate-for.html) where others who applied for immigration job had to paid N1,000.00 each without any job and many died due to poor planning with over $\mathrm{N} 600$ million realized (https://www.premiumtimesng.com/.../238912-exclusive-1-2-million-applicants-jostle). Out of the money realized, N30 million was remitted into the government account, where fuel has become a scarce commodity in a country believed to be one of the largest oil producing countries in the world, and in a country where power has become erratic after spending billions of Naira in the sector (https://www.vanguardngr.com/2015/09/power-obasanjo-yaradua-jonathan-spent-n2-74trn-in-16years), in a country where pipe borne water has become a stranger to the people, where hospitals have become mortuaries as people died as a result of the daily anthem of no drug, no light, no this no that syndrome, where roads have become death traps to road users. In fact, the list is endless. (http://punchng.com/patients-dying-from-lack-of-oxygen-in-nigerian-hospitals).

Politicians must be held accountable! The "...African leader must fit the role of the organ they serve from an ethics perspective, and be developed and self-aware of their limitations and strive for excellence by focusing on strengths, weaknesses and opportunities. Talented ethical individuals' who are potential leaders, should be identified, nurtured and retained and finally afforded an opportunity to make a contribution that is meaningful in a corruption free environment" (Nicolaides \& Duho, 2019). Freire (1999) proposes that liberation requires raising levels of political consciousness of the oppressed so that their new political leaders become conscious of the masses.

If the government is fiscally challenged to the point of defaulting in its statutory duties to workers, the situation in the unorganized private sector can only be better imagined. For less than peanuts, Nigerians slave away in different private firms under horrific conditions. Not only are the salaries 
precipitously meager, safety regulations are literally suspended, as these workers are only too happy to be "employed" to grumble. Many workers in such private organizations have lost their lives without any compensation paid to the families left behind. And the actual tragedy in the whole issue is the pretended ignorance on the part of those in authority on the plight of workers in the country. This is tantamount to betrayal and denouncement of the social contract (https://www.google.com/search?q=social+contract\&ie=utf-8\&oe=utf-8). Labour is considered to be the most important source of value in the production chain and the issue of minimum wage, once legislated should be complied with by all states of the federation, since any infraction will be treated as a criminal offence. The recent agitations by workers in the country for an upward review of N18,000 minimum wage should be approached with serious caution by both the government and the labour unions(http://allafrica.com/stories/201308130192.html) .

Why the problem of cash crunch is so severe in many states to the point of owing their workers up to eight months wages, is due to the insensitivity of governors to 'make hay when the sun shines'. They embarked on white elephant projects, and take loans which are not properly utilized for people in their states. Many claim that their states are 'broke' and in dire need of money but maintain a long convoys of vehicles, aside a lavish domestic budgets, embarking on unproductive trips abroad that have never done their states any significant good and which have not translated to improved standard of living.

Various political figures and company owners organize seminars and symposia outside the country with state money while their workers are wallowing in abject poverty (http://thenationonlineng.net/seven-states-blew-billions-abandoned-projects/).

Many governors accuse workers of various infractions ranging from malingering to incompetence, sloth, and $A$ kií se isé Oba làágùn syndrome. This is apposite to Ehiyamen et.al"s comments that:

The reason is that they see such negative / deviant behaviour, which Include habitual lateness to work, loafing, buck-passing, bribery, corruption, embezzlement or misappropriation of public funds, misuse of government property as counter-productive and therefore detrimental to the accomplishment of organizational goals. ((http://eprints.covenantuniversity.edu.ng/3717/\#.WsXiEU9rzIU).

While most workers can be viewed as being indolent and incompetent, I make bold to say that the bulk of the blame could be directed to the government. On the issue of incompetency, those in governments have thrown merit into the 'dustbin of forgetfulness' and what they hold in high esteem is mediocrity. Nepotism which is any favorable treatment toward relatives that compromises fairness, integrity and neutrality has taken the centre - stage in appointment to government jobs in Nigeria (http://www.theparadigmng.com/2013/05/01/president-goodluck-jonathans-speech-a). What do we expect from such a category of workers? Service delivery is at its lowest ebb in the country because those in the corridors of power have failed in the provision of basic amenities for the people. It would seem therefore that the two elephants (government and workers) are in a co-joined marriage of perpetual discomfort. Nicolaides $(2017 ; 2015 ; 2009)$ also warns that politicians and business leaders need to accept their moral responsibility and the non-commonsensical scope of environmental business relations they follow and begin to consider business strategy and its role in global sustainability far more. He also suggests the application of a transformational eco-centric approach to business activities. There should be set standards which create awareness among politicians, professionals of practices that are susceptible to unethical behaviour and these should guide politicians when making any decisions (Randall, 2012). 
Successive government have made promises to better the lot of Nigerian workers but, it is quite unfortunate that these promises have not made life comfortable for those who are considered to be the pillars upon which the society stands. If the pillars are not strengthened, then the society is likely to crumble. One of such promises is contained in the May Day speech of President Goodluck Jonathan in May 1, 2013.Where he promised that:

The Nigerian worker is not only an important part of our history, but a pivot of our past, present and future. That is why we are leaving no stone unturned towards the practical enhancement of the welfare of all workers in both private and public sectors. Facilitating better relations with employers and government. Since the advent of this administration, our actions and policies have been geared towards placing the country on the path of sustainable progress, where everyone can better achieve his or her dreams. That is the thrust of our transformation agenda.

This has been the anthem of every successive government in the country since independence. But, it has not come to manifestation as levels of poverty among workers in the country have reached an alarming dimension. Also, President Mohammadu Buhari on his May Day speech of 2016 said:

...all over the world, labour remain unarguably an important element in
any policy, programme and project propagated for national development.
In doing so, I request your cooperation and understanding, as partners in
progress the need to ensure a conducive atmosphere devoid of incessant
industrial actions becomes paramount to ensure no loss of man...this
administration shall protect workers' rights and shall promote incentives
for great productivity and hence greater prosperity
(http://www.theparadigmng.com/2013/05/01/president-goodluck-
jonathans-speech-at)

Worried by the vain promises of government, Issa Aremu, one of the union leaders commented on the absence of President Goodluck Jonathan at the workers day celebration of 2015 that:

It is truly tragic that despite the sinking of whopping investment in excess of $\$ 40$ billion for 16 years in the power sector, the only proofs we have to show for it are Megawatts of darkness and Gigabytes of excuses.

( https://guardian.ng/lead-story/jonathan-shuns-may-day-celebration/).

Due to various agitations and protests by the labour unions in the country to press home their demands, many lives have been lost while many who were not killed lost their means of livelihood and they find it extremely difficult to make ends meet. This happened during the military junta and the civilian administrations. For example, President Gbadamosi Babangida terminated the appointment of the former president of the Academic Staff Union of the Universities (ASUU) late Festus lyayi (http://saharareporters.com/2009/12/14/naked-gods-unillorin), Abacha sacked Dr. Azobie, also a former president of ASUU and other branch officers. Under the Obasanjo regime, government sacked 49 ASUU members from the University of llorin. This was carried out by the then Vice Chancellor Professor Oba Shuaib Abdul Raheem (http://saharareporters.com/2009/12/14/naked-gods-unillorin). Also, the government of Osun state in 2000 under the leadership of Chief Bisi Akande sacked about 534 teachers in Osun state. His reason was that some subjects in secondary schools were not viable. Some of the affected subjects were Christian Religious Studies, Social Studies, Yoruba, Islamic Studies, Fine Arts, History, Home Economic, and Government among others (Osun Re-absorbed teachers sacked by Chief Bisi Akande). As a result of this action by the former governor, it became very difficult for many families to eat. This is an outright disregard to the right of Nigerian workers. This is why Adesanya a 52 year old man remarked that: 
I experience a lot of hardship because our pension was not paid. Especially for my first child because the boy suffer a lot. I have to thank God that he did not join bad gang because of the hardship.

The situation in the country is so sad that many workers who have served their country meritoriously during their youthful period are now languishing in penury as a result of non-payment of their entitlements and pension.

\section{Conclusion and Recommendations}

We have endeavoured in this paper to examine the frequent gridlock between Nigerian workforce and the government on issues that affect their welfare. We also consider various types of strikes in Nigeria and their effects on workers, government, students and the nation at large. The research made efforts to look into the causes of strike in Nigeria and came up with the position that the insensitivity on the part of government to see to the welfare of workers has led to the incessant strike. In the work, we examine the values of dignity of labour in the three major religions we have in Nigeria by making references to passages from both the Bible and the Quran, and few sayings, proverbs, tales and fables that deal with value of dignity of labour. The Christian Bible tells us much about godly leadership. It states that "Whoever wants to be a leader among you must be your servant...But select capable men from all the people-men who fear God, trustworthy men who hate dishonest gain and appoint them as officials over thousands, hundreds, fifties and tens" (Exodus 18:21). Good leaders view a great part of their role as developing other leaders. Leadership development takes place in any political party or organization as the really good leaders begin to share their experiences, good and bad, with others so as to improve the lot of those they serve. Good leaders have a heart of total service and they care for and value people and want to help others and do not serve for personal gain. I addition, they are always learning and applying what they learn for the betterment of the nation.

Various promises made by successive administrations have not impacted positively on the lives of the average Nigerian when some of those with connections and in positions of power flaunt their illgotten wealthy around, leaving out workers who have used their productive period to serve the nation meritoriously. The blame according to the argument in this paper is not totally placed at the door of the government alone. Many workers are lazy and indolent and not ready to be committed to their work any longer. Being a servant-leader requires being humble and secure in our individuality and caring for those we serve. If a politician or worker seek the approval of men over the approval of God, they we'll cling to position, power, and authority for ego's sake and not for the right reasons. Labourers and politicians and owners of businesses must all be servant leaders striving to serve humanity with excellence and seeking to deliver value and be a blessing to all people in every interaction.

Government should also enforce compliance with worker-friendly policies deriving from the enforcement of fundamental human rights. Workers and the organized labour should justify their demands so as to ensure that value is added to both the production chain and service delivery. The "Ògá tà, ògá ò tà, owó aláàrù á pé" slogan which is very common among workers should stop and they should make the virtues of hard work, commitment, dedication, sincerity, honesty and contentment their watchwords. Government should also develop a reward and punishment mechanisms among public office holders. We may say that the country is very corrupt. But, we still have many who hold on tenaciously to the dictate of their faiths as servants of the Creator God. Such individuals should be rewarded and honoured with medals and national awards. National awards should be given to deserving members of the public who are corrupt- free and should not be politized as it is the case in our political arena today in Nigeria. Those who deserve to be punished among politicians should be made to face the full force of the law for their actions as the law is not a respecter 
of anyone. Labour union leaders should make it part of their priorities to organize seminars, symposia, conferences and workshops at regular intervals where members will be enlightened on how to apply dedication to duty, punctuality, accountability, and honesty as their watchwords and the need to shun fraud, stealing, bribery and corruption, nepotism and favouritism. Government must also strive to provide better working condition to workers through the provision of the basic necessities of life. To bring out the best in the workers, there should be improved working conditions to better their lots and give them a new lease of life. Most importantly, we should vote for people who are of good repute and trustworthy (Acts 6:3). Leaders who are sheltered in their identity in Christ and modestly aware of their strengths, will always willingly admit their many weaknesses and mistakes. They are the leaders who invite dissenting opinions and give acknowledgement and recognition spontaneously. They encourage the right people in the right roles and allows them the freedom to perform as government servants in the service of the nation.

\section{References}

Aremu, Y. F. et. al., (2015). Implication of Academic Staff Union of Universities on the Academic Performance: Ex-Post-Factor Evidence from University of Lagos, Akoka. Global Journal of Arts, Humanities and Social Sciences, European American Journals, Retrieved on 7th April, 2018. [Available online at https://www.eajournals.org/journals/global-journal-of-arts-humanities-andsocial-sciences-gjahss/vol-3issue-9september-2015/implication-of-academic-staff-union-strikeaction-on-students-academic-performance-ex-post-facto-evidence-from-university-of-lagos-akokanigeria/]

Awoniyi, S. (2013). God and Dignity of Labour in Nigeria: A Moral Perspectives, Journal of Arts and Humanities, 2(7). Retrieved on 13th December, 2017. [Available online at https://doi.org/10.18533/journal.v2i7.183]

Effect of strike action on development. [Available online at https://www.ajol.info/index.php/ijah/article/download/ 107554/97407]. February, 2018.

Effect of strike on Nigeria Economy.articlesng.com/Nigeria-economic _effect_of strike_on_Nigerian_economy-. Retrieved on $7^{\text {th }}$ March, 2018. [Available online at http://dailypost.ng/2017/09/22/breaking-nafdac-staff-commence-indefinite-strike/].Accessed on 2rd March,2018.

Freire, P. (1999). Pedagogy of the oppressed, New York: Continuum Publishing Company.

http://eprints.covenantuniversity.edu.ng/3717/\#.WsXiEU9rzIU. Retrieved on 17 ${ }^{\text {th }}$ February, 2018.

http://ituc-africa.org/IMG/pdf/BENEFITS_REPORT_FINAL_DRAFT.pdf.12/4/2018.

http://punchng.com/patients-dying-from-lack-of-oxygen-in-nigerian-hospitals/.Asseessed on $4^{\text {th }}$ February,2018.

http://saharareporters.com/2009/12/14/naked-gods-unillorin. Retrieved on March, 2018.

http://saharareporters.com/2009/12/14/naked-gods-unillorin.Asseessed on 2rd February,2018

http://thenationonlineng.net/seven-states-blew-billions-abandoned-projects/. Retrieved on 22rd March, 2018. 
http://www.dcemploymentattorney.com/blog/2016/07/nepotism-government-employment/Retrieved on 5th February,2018. Accessed on $6^{\text {th }}$ April, 2018.

http://www.theparadigmng.com/2013/05/01/president-goodluck-jonathans-speech-at. Retrieved on 5th April, 2018.

https://books.google.com.ng/books?id=nkiEIRKY=2MC\&PG=pa184\&pg. Assessed on $8^{\text {th }}$ February, 2018.

https://files.eric.ed.gov/fulltext/EJ1082726.pdf. Retrieved on 1st February,2018.

https://geri-alimi.blogspot.com.ng/2017/06/pensioners-take-to-begging-in-kwara.html. Assessed 12 November, 2017.

https://guardian.ng/lead-story/jonathan-shuns-may-day-celebration/. Retrieved on $7^{\text {th }}$ March,2018.

https://how edu/cgi/viewcontentcgi?article2136\&.Retriieved on $6^{\text {th }}$ March,2018.

https://leadership.ng/.../may-day-nigerian-workers-groan-under-economic-hardship. Retrieved on 4th November,2017.

https://mywage.org/nigeria/home/labour-law/trade-unions.Asseessed on 28th December,2017.

https://nigeriacommunicationsweek.com.ng/nigcomsat-workers-threaten-to-shut-down Retrieved on 12rd February,2018.

https://omojuwa.com/.../asuu-strike-causes-and-implication-of-education-workers-strike.Asseesseed 2/1/2018.

https://qz.com/663626/nigeria-has-a-culture-of-not-paying-workers-and-its-not-about-to-changeanytime-soon/

https://simple.wikipedia.org/wiki/Strike_action.Retrieved on 5th February,2018.

https://workology.com/time-off-request-exempt-non-exempt-employee/.Retrieved on $3^{\text {rd }}$ January, 2018.

https://www. google. com/search?q=how+strike+action+affect+te+education+sector\&ie=utf$8 \&$ oe $=$ utf-8. Retrieved on $8^{\text {th }}$ February, 2018.

https://www. the balance. com > ... > Human Resources > Workplace Communication. Retrieved on $7^{\text {th }}$ March, 2018.

https://www.adamsmith.org/the-wealth-of-nations .Retrieved on 15th February, 2018.

https://www.biblegateway.com/passage/?search=Proverbs+6\%3A6-8\&version..Asseessed on $6^{\text {th }}$ January, 2018.

https://www.business.govt.nz/hiring-and...employment/dismissal-or-termination/Retrieved on 6th March,2018.

https://www.cabrini.edu/about/departments/.../principles-of-catholic-social-teaching. 
https://www.channelstv.com/2016/05/01/full-text-may-day-speech-by-president-muhammadubuhari/Accessed on 3rd March, 2018.

https://www.dailytrust.com.ng/news/education/towards...strikes.../195650.html. Retrieved on 5th March, 2018.

https://www.ethicaltrade.org/faq/isnt-it-job-government-protect-worker. Retrieved on 9th March,2018. https://www.google.com/search?q=airways+workers+strike+of+1959\&ie=utf-8\&oe=utf-8.Asseessed on $9^{\text {th }}$ March,2018.

https://www.google.com/search?q=definition of strike\&i.e=utf-88=ulf. Accessed on $21^{\text {st }}$ January, 2018 https://www.google.com/search?q=macro+and+micro+implications+of+strike+actionon+the+econo my\&ie=utf-8\&oe=utf-

8eprints.covenantuniversity.edu.ng/.../Causes\%20and\%20Effects\%20Industrial\%20crisi...8eprints.c ovenantuniversity.edu.ng/.../Causes\%20and\%20Effects\%20Industrial\%20cris

https://www.google.com/search?q=mercerntile+workers+strike+1951\&ie=utf-8\&oe=utf-8.Asseessed $4^{\text {th }}$ March, 2018.

https://www.google.com/search?q=social+contract\&ie=utf-8\&oe=utf-8. Retrieved on $7^{\text {th }}$ February, 2018.

https://www.google.com/search?q=strike+action+due+to+non+payment+of+entiltilement+and+pensi on+arrears\&ie $=$ utf- $8 \& 0 e=u t f-8$

https://www.google.com/search?q-Nigeria railway workers strike of 1945.Asseessed 2rd February, 2018.

https://www.google.com/search?q-Nigeria railway workers strike of 1939 . Accessed on $13^{\text {th }}$ February, 2018.

https://www.grossarchive.com/.../THE-EFFECT-OF-LECTURER-STRIKE-ON-ACAD. Retrieved 17/2/2018.

https://www.ncbi.nlm.nih.gov/pmc/articles/PMC4962455/ 17th January, 2018

https://www.omicsonline.org/.../low-income-and-diminishing-productivity-in-nigerian. Retrieved on 9th December, 2017.

https://www.pmnewsnigeria.com/.../nafdac-staff-embark-indefinite-strike-demand-imp.Retrieved on 3rd January, 2018.

https://www.premiumtimesng.com/.../202692-panamapapers-ex-nigerian-minister-bou.

https://www.premiumtimesng.com/.../238912-exclusive-1-2-million-applicants-jostle-Retrieved on 27th December, 2018.

https://www.thebalance.com > ... > Human Resources > Workplace Communication.2/4/2018 
https://www.thebalance.com > investing > US Economy > Supply. Accessed on $4^{\text {th }}$ March,2018.

https://www.thenigerianvoice.com/news/144351/1/dignity-of-labour.html. Retrieved on 19th March,2018.

https://www.thoughtco.com > Humanities > History \& Culture > American History. Accessed on $7^{\text {th }}$ March,2018.

https://www.tori.ng/news/.../8-things-you-need-to-know-as-police-fixes-date-for.html. Retrieved on 7th March,2018.

https://www.Vanguardng.com2012/08/Imoundi_released_led_to_re-

organization_of_labour.Retrieved on $4^{\text {th }}$ March, 2018.

https://www.vanguardngr. com > News. Retrieved on $12^{\text {th }}$ January ,2018.

https://www.vanguardngr.com/2015/09/power-obasanjo-yaradua-jonathan-spent-n2-74trn-in-16years. Retrieved on 6th March,2018./

Grint, K. (1991). The Sociology of work: An introduction. Cambridge: Polity Press. See also R.I. Arneson, Meaning of work and Socialization, Ethics, 97(3).

Gyekye, C. (1996). African Cultural Values: An introduction. Philadelphia, Sankofa Publishing Company.

Nicolaides, A. (2020). Ethics and the dignity of work - An Orthodox Christian perspective, Pharos Journal of Theology, 101.

Nicolaides, A. \& Duho, K.C. (2019). Effective Leadership in Organizations: African Ethics and Corruption, Modern Economy, 10, 1713-1743.

Nicolaides, A. (2017). Ethical Practices, Eco-centric Business and Environmental Sustainability, Journal of Human Ecology, 57, 1-2, 1-10, DOI: 10.1080/09709274.2017.1311649

Nicolaides, A. (2015). The paradox of Business Ethics, Quality and Leadership: the path to business sustainability, African Journal of Hospitality, Tourism and Leisure, 4(2) - Special Edition.

Nicolaides, A. (2009). Business ethics in Africa, Journal of Contemporary Management, 61(1), 490501.

Nigerian Minimum Wage and Its Controversy. http://allafrica.com/stories/201308130192.html. Retrieved on 2rd January, 2018.

Okoye, P.V.C. \& Ezejio, R.A. (2013). The Effect of Human Resources Development on Organizational Productivity, International Journal of Academic Research in Business and Social Sciences,10(3), Retrieved on $4^{\text {th }}$ April, 2018.

Osun Re-absorbed teachers sacked by Chief Bisi Akande. http://allafrica.com/stories/200308110161.html.19th

Punch. ng.com. Story by Taiwo Ojoye. Retrieved on $3^{\text {rd }}$ April, 2018. 
punchng.com/many-parents-cant-pay-childrens-fees-abroad-now-come-us-babcock-vc. Retrieved on $8^{\text {th }}$ January, 2018.

Randall, D. (2012). Leadership and the use of power: Shaping an ethical climate, Journal of Applied Christian Leadership, 6(1), 28-35.

saharareporters.com/.../unpaid-salaries-teacher-slumps-school-vice-principal-dead-oyo.Retrieved on $3^{\text {rd }}$ January,2018.

thenationonlineng.net/fed-govt-accuses-lecturers-bad-faith-asuu-begins-strike.Retrieved on $24^{\text {th }}$ February,2018.

Utomi, P. (2004). Dignity of labour. The life Magazine for the victorious life, Lagos: Life Press Limited.

Venturesafrica.com/here_is_how_fall_in_naira_has_affected_the_price_of_food_commodities_in_n igeria. Retrieved on $7^{\text {th }}$ March, $201 \overline{8}$.

Workers groan under unpaid salary and allowances.www.sociallistnigeria.org/print.php?text= Accessed on $23^{\text {rd }}$ February,2018.

www.academia.edu/.../EFFECT_OF_NON-PAYMENT_OF_SALARIES_TO_CIVIL_.Retrieved on 25th March, 2018.

www.cacatholic.org/teachings/catholic-social...encyclicals/rerum-novarum-new-things. Retrieved on 12th March,2018.

www.crcbermuda.com/reference/ellen-white-books.../chap-10-the-dignity-of-labour.Retrieved on 2rd March, 2018

www.mondaq.com/Nigeria/...labour.../An+Appraisal+Of+Types+Of+Employment+An.Asseessed on $18^{\text {th }}$ March,2018.

www.monitor.upeace.org/innerpg.cfm?id_article=938.Asseessed on $24^{\text {th }}$ November,2018.

www.nigerianlawguru.com/../labour\%20law/collective\%20bargaining,\%20. Retrieved on $17^{\text {th }}$ November, 2017.

www.opinions.ng/read-ise-logun-ise-classic-yoruba-poem-j-f-odunjo-english-translati.Retrieved on 30th January,2018.

www.pulse.ng/news/local/Aba-women-riot-of-lgbo-women -who went to war. Retrieved $5^{\text {th }}$ March, 2018. 